\title{
EKSISTENSI SENI PENCAK SILAT DI KABUPATEN PURWAKARTA (Kajian tentang Strategi Adaptasi)
}

\author{
Oleh Irvan Setiawan \\ Balai Pelestarian Sejarah dan Nilai Tradisional Bandung \\ Jln. Cinambo No. 136 Ujungberung Bandung \\ Naskah diterima: 6 Juni 2011 \\ Naskah disetujui: 8 Juli 2011
}

\begin{abstract}
Abstrak
Pencak Silat merupakan warisan budaya Indonesia yang harus dilestarikan. Perkembangan Pencak Silat belakangan ini dapat dikatakan masih berada pada taraf seadanya. Terlihat dari gaung Pencak Silat di Provinsi Jawa Barat yang masih kurang mampu menembus jenis-jenis olahraga ternama seperti sepak bola atau badminton. Sementara dilihat dari segi kesenian juga masih kurang menarik dibandingkan dengan jenis kesenian seperti Wayang Golek ataupun Jaipongan. Walaupun demikian, tidak semua wilayah pasif terhadap upaya pelestarian Pencak Silat. Kabupaten Purwakarta sebagai contoh, merupakan kabupaten terkecil dari Provinsi Jawa Barat yang ternyata memiliki semangat cukup tinggi untuk melestarikan Pencak Silat baik dari segi olahraga ataupun sebagai kesenian tradisional.

Tujuan penelitian ini adalah untuk mendeskripsikan dan menganalisis strategi adaptasi Pencak Silat untuk tetap eksis dan berkembang sebagai bagian dari cabang olahraga maupun sebagai kesenian tradisional di Kabupaten Purwakarta. Metode penelitian yang digunakan adalah deskripsi analisis. Data diperoleh dengan cara pencarian data primer dan sekunder.
\end{abstract}

Kata kunci: Pencak Silat, strategi adaptasi.

\section{Abstract}

Pencak Silat is a kind of Indonesian traditional martial art that has to be preserved because its progress has been poorly gained proper attentions. As an art it is less popular than Wayang Golek or Jaipongan, and as a kind of sport its popularity is not as much as soccer nor badminton. Kabupaten Purwakarta has very high passion to preserve Pencak Silat.

This research tries to describe and analyze the adaptation strategy in maintaining the existence of Pencak Silat in Kabupaten Purwakarta. The author conducted descriptive analytical method, and data were obtained through primary and secondary sources.

Keywords: Pencak Silat, adaptation strategy 


\section{A. PENDAHULUAN}

Pencak Silat, sebuah nama yang tidak asing bagi masyarakat Indonesia untukmenyebutkansebuahalatpertahanan bela diri. Pencak Silat memang terlahir di bumi Indonesia sebagai senjata andalan dalam menghadapi berbagai serangan, baik berasal dari individu, kelompok ataupun pasukan musuh yang berusaha merebut wilayah Indonesia.

Setelah Indonesia merdeka, terjadi penambahan fungsi Pencak Silat dari fungsi vital menjadi fungsi olahraga, kesenian dan hiburan. Bidang kesenian dapat dilihat dari berbagai upacara tradisional yang dalam salah satu tahapannya menghadirkan Pencak Silat. Sebagai contoh adalah tahapan palang pintu dalam upacara perkawinan khas Betawi. Sebagai hiburan, terlihat dari berbagai bentuk ketangkasan memainkan senjata tajam ataupun tangan kosong yang dipertontonkan dalam beberapa media hiburan mulai dari hiburan rakyat sampai ke hiburan media elektronik, seperti acara Gong Show di TransTV. Bela diri sebagai salah satu fungsi utama Pencak Silat kini cenderung menjadi salah satu cabang olahraga yang sama halnya dengan jenis olahraga bela diri lainnya seperti karate, judo, dan lainlain.

Perkembangan Pencak Silat dari segi fungsi sebagai ilmu bela diri itu sendiri ternyata memiliki dua arah yang seakan berlainan. Pertama adalah ilmu bela diri yang telah dilegalisasi menjadi salah satu cabang olahraga tingkat nasional bahkan dunia. Sementara yang kedua adalah ilmu bela diri yang mengarah pada pelestarian kemurnian ajaran Pencak Silat secara tradisional.

Dualisme segi ilmu bela diri yang terjadi dalam Pencak Silat seakan mengalami stagnasi karena perbedaan paham yang sangat kentara. Bela diri dengan menggunakan jurus silat tradisional sudah tentu tidak dapat dipergunakan dalam olahraga bela diri yang dipertandingkan di tingkat nasional karena terbentur aturan yang ketat dan seakan telah mengebiri jurus-jurus Pencak Silat tradisional itu sendiri.

Utamanya dalam segi pelestarian jurus Pencak Silat tradisional, dampak yang terjadi adalah semakin terkikisnya aliran Pencak Silat tradisional karena apa yang mereka banggakan sebagai pendekar silat hanyalah sekadar sebuah ilmu yang tidak terpakai. Sementara istilah pendekar yang "tenar" pada era modern ini adalah menanggalkan "baju pendekar" yang lama dan mengenakan baju Pencak Silat berikut tingkatan yang diatur menurut warna tali pinggang. Mengenakan baju pendekar lama pada saat ini telah dipandang sebagai sosok yang cenderung menakutkan.

Terlepas dari dualisme bela diri seni Pencak Silat ataupun fungsi sebagai bentuk kesenian dan hiburan, mau tidak mau masyarakat harus mengakui bahwa Pencak Silat adalah warisan budaya leluhur bangsa Indonesia yang harus tetap lestari. Sangat disayangkan apabila jurus-jurus ampuh dari berbagai aliran Pencak Silat tradisional terpaksa harus punah terlindas oleh proses regenerasi yang tidak lancar ataupun image semakin menciut. Padahal dari berbagai jurus tradisional mampu dipadukan menjadi jurus andalan dalam olahraga Pencak Silat modern.

Tiap daerah mengalami hal serupa perihal kemunduran di balik kemajuan seni Pencak Silat. Jawa Barat sebagai salah satu gudang berbagai jenis aliran Pencak Silat pun mengalami hal serupa. 
Keampuhan jurus Cimande, Cikalong, dan lain-lain kini terbentur oleh maju tidaknya proses regenerasi dari masing-masing perguruan silat yang mengembangkan aliran silat tersebut.

Purwakarta sebagai sebuah kabupaten terkecil di Jawa Barat ternyata menjadi bagian dari sejarah perjalanan aliran silat terkenal terutama Cimande dan Cikalong. Walhasil, berbagai jurus dua aliran tersebut - atau bahkan lebih - telah diajarkan dan dikembangkan pada masa itu. Beberapa perguruan silat di Purwakarta hingga saat ini masih tetap menggunakan aliran silat yang pernah melintasi daerah mereka ataupun dipadukan dengan jurus silat lainnya sehingga membentuk jurus silat khas perguruan mereka. Ketekunan dari beberapa pesilat Purwakarta telah membuahkan hasil baik dalam beberapa pertandingan antarwilayah. Walaupun demikian, terlepas dari keberhasilan para pesilat Purwakarta tentu di belakang itu semua juga tersirat kemasygulan akan kelangsungan seni Pencak Silat di Purwakarta, mengingat generasi muda saat ini cenderung berkiblat pada budaya global dan mengesampingkan warisan budaya leluhur mereka.

Akankah budaya global mengakibatkan pelestarian seni Pencak Silat semakin sulit diterapkan pada generasi muda di Purwakarta? Jawaban umum yang diperoleh tentu saja diungkapkan dalam bentuk kalimat yang seakan menyadarkan bahwa pelestarian seni Pencak Silat sangat penting bagi kalangan generasi muda. Kelanjutan dari pertanyaan pertama adalah bagaimana caranya? Untuk menjawab pertanyaan kedua ini tentu membutuhkan waktu dan konsentrasi penuh mengingat semua "barang dagangan" yang sangat bagus saat ini telah hadir di depan mata. Daerah-daerah tempat kelahiran ataupun perkembangan seni Pencak Silat tentu merasa tergugah untuk segera bertindak agar salah satu kebanggaan budaya mereka tidak sampai punah.

Masalah yang dihadapi dalam bidang pelestarian seni Pencak Silat adalah bagaimana cara menggugah minat generasi muda agar menyukai dan mencintai seni Pencak Silat? Kesinambungan dari pertanyaan pertama adalah bagaimana bentuk strategi adaptasi yang sesuai dengan keinginan generasi muda untuk kemudian dipadukan dengan keindahan, keampuhan, kewibawaan, dan kehormatan gerakan seni Pencak Silat itu sendiri?

Pencak Silat adalah karya yang diciptakan manusia dalam usaha untuk melindungi diri sendiri atau orang lain dari ancaman bahaya yang ditimbulkan oleh binatang buas atau oleh manusia. Pencak Silat bukan hanya alat perlindungan jasmani belaka, melainkan juga untuk ketentraman rohani. Dengan menguasai Pencak Silat, kekuatan mental manusia akan bertambah tinggi, rohani merasa aman karena tidak takut menghadapi bahaya lagi. ${ }^{1}$

Pencak Silat atau Silat (berkelahi) dengan menggunakan teknik pertahanan diri ialah seni bela diri Asia yang berakar dari budaya Melayu. Seni bela diri ini secara luas dikenal di Indonesia dan Malaysia tapi bisa pula ditemukan dalam berbagai variasi di berbagai negara sesuai dengan penyebaran suku Melayu, seperti di Singapura, Thailand Selatan, Brunei, dan Filipina Selatan. Berkat peranan para pelatih asal Indonesia, saat ini Vietnam

1 Majalah Gema Pencak Silat Tahun ke-4 No 1 Januari 2000 
juga telah memiliki pesilat-pesilat yang tangguh.

Kesenian mengacu pada nilai keindahan (estetika) yang berasal dari ekspresi hasrat manusia akan keindahan yang dinikmati dengan mata ataupun telinga. Sebagai makhluk yang mempunyai cita rasa tinggi, manusia menghasilkan berbagai corak kesenian mulai dari yang sederhana hingga perwujudan kesenian yang kompleks. ${ }^{2}$

Kesenian merupakan bagian dalam kehidupan manusia. Masukan unsur kesenian ini menjadikan manusia dapat berkreasi dalam berbagai bentuk dengan tujuan untuk menambah kehidupan manusia menjadi lebih hidup karena diisi dengan rasa keindahan dan kepuasan batin. Melalui peran yang tergolong sangat penting, perkembangan jenis dan modernisasi kesenian terus berlanjut hingga saat ini.

Modernisasi seni sebagai bagian dari proses evolusi - atau revolusi ? adalah sebuah perubahan yang tentu akan membawa dampak terhadap kehidupan seni asli, atau dapat dikatakan seni tradisi, yang ada sebelumnya. Dan, modernisasi seni ternyata telah masuk begitu jauh dalam bagian-bagian wujud seni tradisi, yang menurut Permas (Permas et.al, 2003) terbagi dalam 2 bagian. Bagian pertama dapat berwujud seni tradisi ritual untuk upacara-upacara keagamaan dan adat, kemudian bagian kedua adalah wujud seni tradisi yang dikemas khusus untuk dinikmati masyarakat luas maupun wisatawan (arts for mart). Triono Saputro (2005), dalam kaitannya dengan hubungan antara bagian-bagian yang ada dalam wujud seni tradisi menambahkan bahwa:

2 Lihat http://www.fellowshare.com/id/ Kebudayaan.htm\#Pengertian "kedua bentuk seni tradisi tersebut, saat ini memang masih ada dan ternyata dapat hidup berdampingan. Masing-masing bentuk memiliki habitat, pendukung, dan aturan main sendiri, yang tidak perlu dipertentangkan dan dicampuradukkan. Kalau masing-masing bentuk seni tradisi dapat berkembang di habitatnya masing-masing dan tidak saling bertentangan, terdapat potensi sinergi yang baik antarkeduanya."

Maksud penelitian ini adalah untuk mendeskripsikan sekaligus menganalisis berbagai proses strategi adaptasi yang dilakukan pemerhati, penikmat, ataupun pelaku seni Pencak Silat kepada masyarakat luas terutama di Kabupaten Purwakarta. Hasil dari penelitian ini diharapkan menjadi salah satu rujukan bagi instansi terkait yang berkecimpung dalam bidang pelestarian kebudayaan khususnya Pencak Silat.

Penelitian ini menggunakan metode kualitatif untuk mendeskripsikan perkembangan Pencak Silat di Kabupaten Purwakarta berikut strategi adaptasi yang pernahdansedangdijalankandalamkaitan dengan pelestarian dan pengembangan seni Pencak Silat itu sendiri. Analisis lebih diutamakan pada bentuk kajian strategi adaptasi yang dijalankan berikut sedikit ada komparasi dengan strategi adaptasi yang dijalankan di wilayah lainnya. Beberapa literatur juga turut disertakan dalam analisis ini dengan maksud untuk memperkuat sekaligus memberikan solusi bagi perkembangan seni Pencak Silat itu sendiri. 
Data yang dikumpulkan meliputi dua jenis yaitu data primer dan data sekunder. Terkait dengan pengumpulan data primer, penelitian yang bersifat kualitatif membutuhkan beberapa peralatan pengumpulan data primer yang lebih akurat, dan tidak sekadar memberikan kuesioner kepada responden.

Selain data primer, data sekunder juga sangat diperlukan dalam penelitian ini mengingat Pencak Silat dapat dikatakan bukan merupakan sebuah objek penelitian yang bersifat eksploratif lagi karena dari beberapa studi literatur telah ada penelitian yang mengambil objek serupa. Oleh karena itu, data sekunder sangat berguna untuk mendukung data primer sekaligus memberi wawasan yang lebih luas tentang arti dari strategi adaptasi. Perolehan data sekunder dapat dicari di beberapa perpustakaan instansi, perpustakaan umum, perpustakaan atau koleksi pribadi serta melalui media massa dan elektronik.

\section{B. HASIL DAN BAHASAN}

\section{Gambaran Umum Kabupaten Purwakarta}

Kabupaten Purwakarta terletak di antara $107^{\circ} 30^{\prime}$ - 107 $40^{\prime}$ BT dan 6 $6^{\circ} 5^{\prime}$ $6^{\circ} 45^{\prime}$ LS. Sementara apabila dilihat dari posisi wilayah administratif, Kabupaten Purwakarta mempunyai batas wilayah bagian Barat dan sebagian wilayah bagian Utara berbatasan dengan Kabupaten Karawang; bagian Utara dan sebagian wilayah bagian Timur berbatasan dengan Kabupaten Subang; bagian Selatan berbatasan dengan Kabupaten Bandung; dan bagian Barat Daya berbatasan dengan Kabupaten Cianjur.
Wilayah Purwakarta juga dapat dikatakan berada pada titik temu pada tiga jalur utama lalu lintas yang tergolong strategis, yaitu jalur Purwakarta-Jakarta, Purwakarta-Bandung dan PurwakartaCirebon. Secara administratif, Wilayah Kabupaten Purwakarta terdiri atas 17 kecamatan, 183 desa dan 9 kelurahan. Dalam lingkup administratif yang lebih kecil lagi, Purwakarta terbagi dalam 490 Dusun, 1.056 RW (Rukun Warga), dan 3.071 RT (Rukun Tetangga).

Pertumbuhan dapat terlihat melalui tingkatan usia. Jumlah yang cukup mencolok dalam laju pertumbuhan penduduk adalah pada tingkat $0-4$ tahun. Dengan demikian dapat diidentifikasikan bahwa ada banyak pasangan muda berada di Kabupaten Purwakarta. Kenaikan lima besar pada tingkatan golongan umur selanjutnya secara berturut-turut ada pada tingkatan 15 - 19 tahun, 30 - 34 tahun, 20 - 24 tahun, dan $35-29$ tahun. Indikasi pada laju pertumbuhan penduduk dalam tingkatan usia tersebut dapat diterjemahkan bahwa ada lebih banyak golongan masyarakat usia produktif dibandingkan golongan yang sudah mulai tidak produktif. (Sumber : Setda Kab. Purwakarta, Tahun 2008)

\section{Sejarah Singkat Pencak Silat di Kabupaten Purwakarta}

Pencak Silat merupakan salah satu bentuk tindakan untuk menjaga fisik (termasuk mental) secara individual dalam menghadapi bahaya. Hal ini memungkinkan bahwa Pencak Silat dapat saja disamakan dengan sejarah survival of the Ofittest perjalanan manusia di muka bumi hingga survive seperti saat ini. Inti dari pembelaan diri yang dimaksud tentunya mengarah pada tindakan fisik 
yang merupakan rangkaian dari gerakan yang terlatih sehingga menciptakan sebuah pola terbaik tentang bagaimana perilaku tubuh mampu menghadapi bahaya. Pola gerakan silat yang pada akhirnya dinamakan jurus ini pada masa dahulu digunakan untuk menghadapi binatang buas dalam mempertahankan hidupnya. Mereka menciptakan bela diri (jurus-jurus) dengan meniru gerakan binatang yang berada di lingkungan alam sekitarnya.

Belajar dari alam adalah ide terbaik manusia pada masa dahulu untuk mampu bertahan dalam menghadapi bahaya. Penghuni alam baik flora maupun fauna di sekitar manusia diperhatikan gerak, karakter, dan sifatnya untuk kemudian diambil intisarinya dan diterapkan sebagai sebuah jurus sesuai dengan karakter dari flora dan fauna yang dipelajari sebelumnya. Misalnya jurus yang diciptakan meniru gerakan harimau, kera, ular, dan burung. Oleh karena kondisi lingkungan yang berbukit dan berbatuan, maka gerakannya banyak lompatanloncatan. Orang-orang yang hidup di pegunungan biasa berdiri, bergerak, berjalan dengan langkah kedudukan kaki yang kuat untuk menjaga agar tidak mudah jatuh selama bergerak di tanah yang tidak rata. Biasanya menciptakan bela diri yang mempunyai ciri khas kuda-kuda yang kokoh tidak banyak bergerak. Adapun gerakan tangan lebih lincah, banyak ragamnya dan ampuh daya gunanya.

Penduduk yang hidup di daerah berawa, tanah datar, padang rumput biasa berjalan bergegas, berlari, sehingga gerakan kakinya menjadi lincah. Mereka menciptakan bela diri yang lebih banyak memanfaatkan kaki sebagai alat bela diri. Akhirnya setiap daerah mempunyai bela diri yang khas dan berbeda dengan daerah lainnya, sehingga timbulah aliran bela diri beraneka ragam. Kemudian pertemuan antara penduduk daerah yang satu dengan daerah yang lain, menyebabkan terjadinya tukar menukar ilmu bela diri, sehingga dapat meningkatkan mutu bela diri di setiap daerah.

Kabupaten Purwakarta yang memiliki kontur tanah bergelombang tentunya memiliki karakteristik masyarakat yang menyesuaikan diri dengan keadaan geografis tersebut, seperti mata pencaharian yang banyak mengandalkan kondisi tanah akan menggunakan pola tanam yang memilih jenis perkebunan misalnya daerah Wanayasa. Sementara untuk kategori tanah datar seperti di daerah mulai dari Pasawahan dan Maracang, mereka lebih memilih untuk mengandalkan pola tanam persawahan. Dihubungkan dengan kondisi geografis dan mata pencaharian (petani dan pekebun), dalam dunia persilatan pun mereka cenderung untuk memilih pola atau jurus yang juga disesuaikan dengan karakteristik kondisi geografis dan mata pencaharian mereka sendiri.

Gerakan untuk mengikuti pola geografis tentunya diikuti dengan penghuni alam (fauna) itu sendiri seperti gerakan macan (pamacan) ${ }^{3}$, dan monyet (pamonyet) ${ }^{4}$. Mengenai gerakan

3 Dinamakan pamacan karena gerakan yang diperlihatkan meniru gerakan yang biasa dilakukan macan saat menyerang mangsanya. Berbeda dengan jurus pamacan ilmu hitam yang selain meniru gerakan juga memperlihatkan perubahan fisik seperti kuku menjadi panjang, mengeluarkan suara-suara aneh, dan mata merah.

4 Dinamakan jurus monyet/pamonyet 
yang mengikuti gerak gerik fauna pada beberapa jurus Pencak Silat memang telah lama ada di Purwakarta. Selain dipengaruhi oleh unsur alam, aliran silat yang ada di Kabupaten Purwakarta tidak lepas dari pengaruh tokoh silat yang cukup terkenal dan pernah bermukim di Wanayasa. Ia adalah Mama Kosim yang terkenal dengan seni maenpo. ${ }^{5}$

Maenpo Sahbandar (Syahbandar/ Sabandar) pertama kali diperkenalkan oleh Muhammad Kosim (lebih dikenal sebagai Mama Kosim - Mama adalah panggilan hormat untuk ulama besar atau guru besar dalam bahasa Sunda). Seperti juga tokoh dari aliran lainnya, asal dari Mama Kosim sendiri dan

karena jurus ini sangat menyerupai perilaku monyet yang gesit, mampu meloncat ke atas, ke samping dan ke belakang, bahkan berguling-guling.

5 Maenpo merupakan salah satu bentuk seni Pencak Silat yang berasal dari daerah Cianjur. Pengertian maenpo sendiri berasal dari dua buah suku kata yaitu maen dan po. Maen adalah bermain sepertil layaknya permainan lainnya. Sementara po berasal dari kata poho yang dalam bahasa Sunda berarti lupa. Pengertian lupa bisa saja sebagai artian agar permainan tersebut untuk mengisi waktu luang atau dapat diartikan apabila telah "bermain" maka segala hal yang berkenaan dengan permainan tadi harus dilupakan terutama bagian yang tidak mengenakan hati. Kata maenpo ada juga yang menjadikannya akronim kata maen anu euweuh tempo yang di populerkan oleh Raden Haji Tarmidi (keponakan dari Raden Haji Ibrahim Jayaperbata). Arti dari kalimat tersebut adalah bahwa maenpo merupakan seni Pencak Silat dengan aliran jurus dengan tempo permainan yang sangat cepat sehingga sangat sulit untuk dibendung lawan.
Maenpo yang diajarkan memiliki banyak versi. Meskipun begitu, semua versi menyebutkan bahwa beliau adalah keturunan keluarga terkemuka dari Sumatra Barat, hanya masih dipertentangkan apakah berasal dari Solok, pesisir Padang, Pagaruyung atau Bukit Tinggi.

Nama Mama Kosim mulai ramai dibicarakan ketika salah seorang murid dari Maenpo Cikalong menjadi muridnya. Pembicaraan mengarah pada lokasi tempat tinggal Mama Kosim yaitu di Kampung Sahbandar - Karang Tengah - Cianjur. Ia tinggal di sana sekaligus menjadi salah seorang santri dari Ajengan Cirata. Pelajaran yang diberikan berupa Tarekat Nasbandaqiyah yang dibimbing langsung oleh Ajengan ${ }^{6}$ Cirata ${ }^{7}$. Sumbangsih Mama Kosim selama menimba ilmu Tarekat Naqsabandiyah yang diberikan Ajengan Cirata adalah pelajaran Maenpo Sahbandar - secara tertutup - yang diajarkan kepada para santri di pesantrennya Ajengan Cirata, bahkan Ajengan Cirata sendiri merupakan murid Maenpo nya Mama Kosim.

Mama Kosim bersama dengan Ajengan Cirata kemudian pindah ke Sindang Kasih di Purwakarta. Keputusan menetap di Purwakarta hingga akhir hayat ditetapkan Mama Kosim setelah istrinya meninggal di Sindang Kasih. Bukan hanya

6 Ajengan adalah bahasa Sunda yang harfiahnya hampir sama seperti Gus di Jawa Tengah atau Jawa Timur

7 Ajengan Cirata adalah seorang sesepuh daerah Cirata, sebuah lokasi yang saat ini menjadi sebuah waduk sekaligus berfungsi sebagai PLTA pembangunan Waduk Cirata yang dimulai pada bulan Desember 1983 dan berakhir September 1988 dengan kekuatan 5000 tenaga kerja (300 di antaranya berasal dari Jepang). 
itu saja, alasan menetap di Purwakarta adalah untuk berdakwah, yaitu mengajar ilmu agama di Mesjid Agung Wanayasa sekaligus mengembangkan lebih jauh Maenponya di sana. Di Wanayasa, Mama Kosim mempererat hubungan dengan keluarga besar Maenpo Cikalong. Beliau mengajar ilmu agama dan Maenpo Sahbandar di Wanayasa sampai akhir hayatnya pada tahun 1880 .

\section{Aliran dan Jurus Silat yang Ada di Kabupaten Purwakarta}

\section{a. Silat Paleredan}

Paleredan dapat diartikan sebagai ibing dan bisa disebut juga sebagai salah satu bentuk kesenian yang sangat terkait erat dengan Pencak Silat. Paleredan merupakan salah satu bentuk kesenian Pencak Silat yang saat ini tergolong aktif tidak hanya di Kecamatan Plered saja tetapi telah tersebar di 17 kecamatan dalam wilayah Kabupaten Purwakarta. Keaktifan kesenian secara tidak langsung didorong oleh adanya kebiasaan untuk menampilkan kesenian Pencak Silat Paleredan sebagai salah satu bagian dalam upacara penyambutan tamu kehormatan mulai dari setingkat kepala desa atau bahkan pejabat negara. Antusias penonton terhadap kesenian ini juga terlihat sangat positif karena di setiap tampilan para penonton terlihat lebih banyak dan menikmati saat kesenian ini ketika digelar.

Kesenian Pencak Silat Paleredan berkembang terlebih dahulu di daerah Plered.Halinidilatarbelakangipenggalian warisan budaya yang intens oleh para sesepuh masyarakat Plered. Warisan budaya Paleredan berkembang tatkala telah adanya seni Pencak Silat di bumi Sunda pada tahun 1828. Sosok Raden
Tisna Wijaya (bermukim di CikalongCianjur), Bang Madi dan Mbah Khair berhasil melakukan pembaruan jurusjurus silat yang kemudian terciptalah jurus Cimande dan Cikalong. Jurus ini merupakan hasil dari pengembangan aliran Pencak Silat yang sudah ada sebelumnya seperti aliran Syahbandar, Damalun, dan Godot.

Tujuh puluh empat tahun kemudian (1892) hingga tahun 1952 anak Raden Tisna Wijaya yaitu Raden Abu Kosim dan adiknya Raden Didi Djunaedi yang hijrah dan menetap di wilayah PleredPurwakarta mulai mengembangkan aliran Pencak Silat ciptaan orangtua mereka. Perguruan silat pun mereka dirikan dan diberi nama Perguruan Silat Tali Wargi. Konsentrasi terhadap pembaharuan jurus di perguruan silat yang mereka dirikan itupun berhasil dan mereka menyebutkan jurus baru tersebut dengan nama jurus silat "Cilalawi Pleredan". Proses turun temurun jurus Paleredan kemudian terus berjalan. Demikian pula dengan jurus silat "Cilalawi Pleredan", jurus ini diturunkan kepada Raden Mangkudirja. Jurus silat Cilalawi Pleredan terus mengalami pembaharuan, dan pada tahun 1957 bersama dengan Mbah Duyeh dikembangkan jurus silat "Paleredan" dalam versi yang lebih lengkap, mulai tepak irama kendang, lagu khas Paleredan, dan Jurus Lima. Dengan versi yang lebih lengkap tersebut, jurus Pencak Silat Paleredan Purwakarta saat ini telah mendapat pengakuan dari Persatuan Pencak Silat Seluruh Indonesia. ${ }^{8}$

\section{b. Aliran Cimande}

Aliran Cimande juga menjadi salah satu aliran silat yang cukup berpengaruh

8 Lebih lanjut, lihat "Seni Pencak Silat Paleredan", dalam http://www. 
di Purwakarta. Perjalanan aliran silat Cimande di Purwakarta ini tidak luput dari sepak terjang Mbah Kahir, seorang yang bergelar kiai sekaligus pencipta aliran silat Cimande. Pencak Silat aliran Cimande pertama kali diciptakan dari seorang Kiai bernama Mbah Kahir ${ }^{9}$. Mbah Kahir adalah seorang pendekar Pencak Silat yang disegani. Pada pertengahan abad ke - XVIII (kirakira tahun 1760), Mbah Kahir pertama kali memperkenalkan kepada muridmuridnya jurus silat. Oleh karena itu, ia dianggap sebagai Guru pertama silat Cimande.

Mbah Kahir bertempat tinggal di Kampung Cogreg, Desa Cogreg ${ }^{10}$, Kecamatan Parung, Bogor, di tepi Sungai Cimande. Di lokasi kediamannya tersebut ia berhasrat untuk menurunkan keahlian silatnyakepadapenduduksekitar. Ternyata informasi mengenai jurus silatnya makin berkembang. Ajaran silatnya disukai murid-muridnya, sehingga beliau berhasrat untuk mengembangkan ajarannya ke luar daerah. Alhasil ajaran silat tersebut berhasil tersebar mulai dari sekitar wilayah Bogor hingga meliputi sebagian besar daerah Jawa Barat, seperti Jakarta, Bekasi, Karawang, Cikampek, Purwakarta, Subang, Priangan (Sukabumi, Cianjur, Bandung, Garut, Tasikmalaya, Sumedang, Ciamis, Kuningan, dan Cirebon).

\section{beritaindonesia. co.id/index.php}

9 Sebutan lainnya dari mbah kahir adalah mbah/eyang/abah/kyai Kaher, Kair, Kaer.

10 Di Desa Cogreg ini juga tepatnya di Kampung Jeletreng terdapat Makam Mbah Dengkong, seorang tokoh masyarakat yang dihormati di Desa Cogreg
Jurus silat Cimande di Kabupaten Purwakarta adalah sama dengan jurus silat Cimande di daerah lainnya. Persamaan tersebut dapat dilihat dari garis besar jurus Pencak Silat Cimande yang meliputi tiga bagian, yaitu Jurus Kelid Cimande, Jurus Pepedangan, dan Jurus Tepak Selancar. Dua jurus pertama termasuk dalam kategori bela diri, sedangkan jurus terakhir (Tepak Selancar) dimasukkan dalam kategori seni. ${ }^{11}$

Kelid dalam bahasa Sunda dapat diartikan sebagai tangkisan. Dengan demikian ciri khas Jurus Kelid Cimande adalah dari segi tangkisan yang disertai dengan pukulan untuk menyerang lawan dan berusaha merubuhkannya. Adapun jurus Kelid Cimande terbagi lagi dalam 33 jurus, yaitu: tonjok bareng, tonjok sabeulah, kelid, selup, timpah sabeulah, timpah serong, timpah dua kali, batekan, teke tampa, teke purilit, tewekan, kedutan, guaran, kedut guar, selup tonjok, kelid tilu, kelid lima, selup lima, peuncitan, timpah bohong, serong panggul, serong guwil, serong guar, singgul serong, singgul sabeulah, sabet pedang, beulit kacang, pakala alit, pakala gede.

Dari 33 jurus Kelid tersebut, tampak bahwa kelid atau tangkisan banyak bertumpu pada tangkisan tangan. Hal itu dapat diperhatikan dari kelompok jurus seperti tonjok, kelid, batekan, teke, tewekan, kedutan, dan guaran. Tonjok dicirikan dengan bentuk tangan yang mengepal, teke dilakukan dengan menggunakan ruas jari tangan, tewekan

11 Siti M, Herliswanny R, “Apresiasi Generasi Muda terhadap Pencak Silat di Daerah Jawa Barat", dalam www.beksi. wordpress.com 
diperlihatkan dengan bentuk tangan yang menusuk. Jurus kedutan dilakukan dengan menggunakan telapak tangan, dan jurus guaran menggunakan sisi tangan luar maupun dalam. Dengan demikian untuk melatih jurus Kelid ini, peserta banyak melakukan dengan posisi duduk di tempat. Hal ini agar posisi kaki tidak ikut berperan dalam melindungi tubuh. Apabila dilakukan sambil berdiri maka kelihaian tangan yang banyak berperan dalam jurus Kelid ini dapat terganggu.

Proses pelatihan dilakukan berpasangan dengan posisi duduk berhadap-hadapan sementara posisi kaki sebelah dilipat dan sebelah lagi dilonjorkan ke depan. Tujuan menggunakan pola duduk seperti itu adalah untuk melatih imajinasi dalam menentukan kuda-kuda yang terbaik saat dalam posisi berdiri. Selanjutnya, posisi duduk tersebut juga dapat mempermudah menerapkan strategi selanjutnya setelah berlatih jurus terdahulu

Berbeda halnya dengan jurus Kelid, jurus selanjutnya yaitu jurus Pepedangan. Jumlah jurus Pepedangan berjumlah 13 jurus, yaitu: ela-ela sabeulah, selup kuriling, jagangan, tagogan, piceunan, balungbang, balumbang, sabeulah, opat likur, buang dua kali, selup kuriling langsung, selup bohong.

Pola jurus Pepedangan ini banyak menggunakan kaki. Pepedangan yang dalam bahasa Sunda adalah pedang, diartikan secara sebenarnya yaitu peserta dalam akhir pelatihan mahir dalam menggunakan pedang. Dengan demikian posisi kaki sangat menentukan saat peserta memainnkan pedang. Ada dua posisi kaki, yaitu kaki sejajar, kaki serong, dan tagogan. Kaki sejajar adalah posisi berdiri dengan posisi kaki sejajar antara kanan dan kiri. Sementara itu jenis kaki serong dilakukan dengan posisi kaki miring dengan membentuk sudut 45 derajat. Selanjutnya tagogan adalah posisi kaki merendah dengan posisi tumit kaki menempel pada pinggul dengan posisi kaki yang sedikit berjingkat.

Jurus ketiga, yaitu Jurus Tepak Selancar dapat dikatakan sebagai jurus tambahan yang biasanya hanya ditampilkan pada acara pembuka. Hal ini disebabkan jurus Tepak Selancar lebih diarahkan pada unsur seni. Terkait dengan unsur seni dalam jurus ini maka diperlukan waditra sebagai pengiring sekaligus aba-aba pola gerak yang telah diatur sebelumnya. Adapun waditra yang diperlukan terdiri atas 2 buah gendang besar, 2 buah kulanter 'gendang kecil', sebuah terompet sebagai melodi lagu, dan sebuah kempul 'gong kecil atau bende'. Utama dalam aba-aba musik pengiring adalah kendang. Dengan demikian sangat diperhatikan oleh para pemain saat peragaan tiap perubahan dalam pola tepak kendang. Oleh karena itu peraga harus mengerti juga motif dalam setiap tepak kendang yang telah dipilah dalam empat jenis tepak, yaitu tepak dua, tepak tilu, golempang, padungdung. ${ }^{12}$

\section{c. Pencak Silat Beksi}

Kehadiran Silat Beksi di Purwakarta memang baru-baru ini saja hadir di Purwakarta. Berbekal keahlian memainkan jurus Silat Beksi, ia kemudian

12 Lebih lanjut lihat, "Silat Cimande Sejarah dan Perkembangannya", dalam http://74.125.153.132/ search? q=cache:jLdk9LzsIoJ:bogorbarat. info/2009/10/07/silat-cimande/+silat + Purwakarta\& $c d=27 \& h l=i d \& c t=c l n$ $k \& g l=i d \&$ client $=$ firefox $-a$, tanggal 7 October 2009 
sedikit demi sedikit menularkan ilmunya kepada murid-murid di sekitar rumahnya. Lambat laun jumlah murid semakin bertambah karena berita dari mulut ke mulut mengenai teknik Silat Beksi yang dianggap mereka cukup memikat dan mampu membuat lawan terkesima.

Secara sekilas, Silat Beksi hampir mirip dengan teknik aikido, sebuah seni bela diri khas Jepang. Walaupun demikian, latar belakang Silat Beksi sangat tidak terkait dengan bela diri khas Jepang tersebut. Silat Beksi adalah hasil akulturasi budaya China dan Betawi. Hal ini dapat dilihat dari sejarah kelahiran Silat Beksi. Silat Beksi diciptakan Lie Cheng Oek, warga keturunan China yang tinggal di Kampung Dadap, Tangerang, Banten. Lie adalah seorang pendekar silat beraliran Shaolin Utara di China.

Ilmu Lie Cheng Oek diturunkan ke anaknya Lie Tong San, kemudian diturunkan lagi ke cucunya, Lie Gie Tong. Selain itu, Lie Cheng Oek juga punya beberapa murid lain yaitu Ki Marhali, Engkong Haji Ghozali, dan Engkong Haji Hasbullah. Lie Gie Tong pun mengakui ketiga orang ini sebagai pewaris ilmu sang kakek. Pencak Silat Beksi banyak berkembang di Jakarta Selatan seperti di Cipulir, Kebayoran Lama, juga di Bintaro, Karawang dan Bekasi.

Silat Beksi memiliki 9 formasi, 12 jurus dan 6 jurus kembangan yang harus dikuasai setiap murid. Beksi mengandung filosofi dari setiap hurufnya, 'Berbaktilah Engkau Kepada Sesama Insan'. Filosofi ini menjadi landasan kebijaksanaan para pendekar Beksi. Sementara kata Beksi aslinya berasal dari bahasa China, Bek berarti pertahanan, Si berarti empat. Sehingga Beksi berarti empat pertahanan. ${ }^{13}$

\section{d. Pencak Silat Bela diri PII}

Pencak Silat Bela diri Pelajar Islam Indonesia (PSBD PII) didirikan di Purwakarta atas prakarsa Bang Eddi Jaya dan Korpus Brigade PII sekitar tahun 90an. Latar belakang pendirian organisasi PSBD PII adalah pertahanan diri serta ideologi organisasi yang mewadahi perkumpulan tersebut. Atas dasar itu, para anggota wajib untuk ikut dalam pelatihan, baik latihan tingkat dasar atau dalam istilah PSBD PII adalah LBTD (Latihan Brigade Tingkat Dasar) maupun LBTL (Latihan Brigade Tingkat Lanjut).

Penciptaan Pencak Silat khas PSBD PII berlatarbelakang pengalaman Eddi Jaya saat mengikuti pelatihan dari berbagai perguruan silat. Hasil dari pelatihan tersebut kemudian dirangkum menjadi seni Pencak Silat yang wajib dikuasai oleh anggota PSBD PII. Teknik yang diajarkan berupa seni bela diri praktis dalam bentuk teknik pembelaan pukulan, pembelaan tendangan, pembelaan serangan dengan senjata, hingga pembelaan kuncian. Selanjutnya turut diajarkan teknik serangan pukulan, tendangan, sapuan dan guntingan. ${ }^{14}$

\section{e. Jurus Payung Rasul Margaluyu}

Jurus Payung Rasul, sebagai salah satu jurus yang juga berkembang di Purwakarta tidak luput dari peranan Mang

13 M. Rizal Maslan Rabu, "Melestarikan Silat Beksi Ciaat! Silat Betawi Rasa Shaolin", dalam http://www.detiknews. com/read/2010/05/26/162101/136460 1/159/ciaat-silat-Betawi-rasa-shaolin 26/05/2010 16:21 WIB

14 "Pencak Silat Beladiri PII", dalam http:// psbdpii.blogspot.com/2009/10/psbd-pii. html Kamis, 15 Oktober 2009 
Uwen sebagai salah seorang tokoh silat dari keilmuan Margaluyu. Jurus Payung Rasul itu sendiri merupakan inti sari dan perasan ilmu silat warisan keluarga Abah Andadinata yaitu ilmu peksi muih. Dengan demikian, jurus Payung Rasul merupakan salah satu jurus yang sangat terkenal dalam aliran Silat Margaluyu. Margaluyu itu sendiri merupakan aliran atau jurus yang mengandalkan olah nafas aliran Alhikmah. Sebelum andalan olah nafas Alhikmah, aliran Margaluyu didasarkan atas tradisi maenpo khas Cianjur. Tradisi yang kerap diisi dengan pertarungan dan ibingan ini kemudian sedikit demi sedikit dipengaruhi oleh ilmu keislaman mengingat $\mathrm{S}$. Andadinata - selaku pendiri Gerak Badan Pencak Margaluyu Pusat - pernah berguru pada Syeh Haji Abdul Kahpi dan Ajengan Asep Samsudin dan beberapa tokoh Islam lainnya di Cianjur. Sampai akhir hayatnya Abah Andadinata bermukim J1. Ir. H. Juanda no. 56 desa Cikuya kecamatan Cicalengka. Beliau wafat pada petang hari tanggal 29 Januari 1969 pada usia 76 tahun dan dimakamkan di tempat yang sama pada tanggal 30 Januari 1969 di Desa Cikuya, Cicalengka.

Selain di Purwakarta, jurus Payung Rasul kemudian tersebar seiring dengan meluasnya keilmuan Margaluyu Pusat melalui para tokoh silatnya seperti, Mang Andi Rohandi dan Ishak Zaenudin yang mengajarkan jurus Payung Rasul di daerah Cicalengka; Mang Suwandi yang berkiprah di Bandung; Sumo Prawiro, Soekabjo, dan Suwaryono mengajarkan jurus tersebut di Yogyakarta; dan Mulyoharjo mengajarkan jurus Payung Rasul di daerah Lampung. Proses pelatihan dalam Gerak Penca Payung Rasul Margaluyu di Kabupaten Purwakarta adalah sama dengan apa yang diajarkan dalam kurikulum Gerak Pencak Margaluyu Pusat.

\section{f. Pencak Silat Sanalika}

Pencak Silat Sanalika yang didirikan oleh Utuk Sumadipradja dari Garut telah menjadi bagian dari aliran Pencak Silat di Purwakarta melalui sepak terjang Kandi yang lahir di Cipatat tahun 1933. Selain di Purwakarta, Kandi telah lebih dahulu menyebarkan jurus Pencak Silat Sanalika ke Kabupaten Bandung dan berakhir di Purwakarta. Kandi merupakan murid pertama dari Utuk Sumadipradja yang telah menyebarkan ilmu Silat Sanalika ke daerah di luar Kabupaten Garut. Selain Kandi, beberapa generasi pertama murid Utuk yang menyebarkan Pencak Silat Sanalika ke luar Garut adalah Ateng Karta (lahir di Bojong Salam Garut 1926) yang menyebarkan Sanalika ke wilayah Bandung; Iko (lahir di Bojong Salam, Garut 1926) menyebarkan Sanalika di Pangalengan; dan Achmad Dimyati (lahir di Sukabumi, 1940) menyebarkan Sanalika ke daerah Sukabumi dan Cianjur dengan pusat pelatihan ada di Sukaraja, Sukabumi.

Perguruan Pencak Silat Sanalika itu sendiri lebih dikenal dengan nama Paguron Penca Sanalika. M. Utuk Sumadipradja berhasil mendirikan perguruan ini pada tahun 1926, yakni saat beliau menjabat sebagai Camat Bojong Salam, Garut. Pada sekitaran tahun tersebut $(1926$ - 1930) telah ada beberapa perguruan silat yang hampir bersamaan dirikannya dengan paguron Penca Sanalika, yaitu Perguruan Silat Panglipur (1909), Perguruan Silat Timbangan (1927), Perguruan Silat Pusaka Siliwangi (1930), dan Perguruan Silat Nampon (1932). 
Jurus yang menjadi andalan dalam Paguron Penca Sanalika adalah Jurus Tujuh. Jurus Tujuh yang dimaksud bukan murni Jurus Tujuh yang dimiliki oleh Silat Sahbandar karena telah digabungkan dengan gerakan atau aliran dari Cimande dan aliran silat Kari, serta Silat Cikalong. Inti dari masing-masing aliran tersebut kemudian dipadukan ke dalam Jurus Tujuh yang merupakan jurus dasar dalam Paguron Silat Sanalika. Hasilnya adalah sebuah jurus yang tergolong ampuh dan menjadi kebanggaan dalam Paguron Penca Sanalika dan setiap murid wajib untuk menguasai Jurus Tujuh tersebut.

\section{Strategi Adaptasi Ditinjau dari Aspek Mental Spiritual}

Dalam strategi adaptasi Pencak Silat yang ditinjau dari aspek Mental Spiritual, Pencak Silat membangun dan mengembangkan kepribadian dan karakter mulia seseorang. Para pendekar dan maha guru Pencak Silat zaman dahulu seringkaliharus melewatitahapan semadi, tapa, atau aspek kebatinan lain untuk mencapai tingkat tertinggi keilmuannya. Beberapa perguruan silat baik yang terorganisir ataupun hanya merupakan kumpulan beberapa warga yang berlatih silat di bawah naungan seorang pelatih silat, unsur mental spiritual tidak lepas menyelimuti setiap gerakan silat. Sosok mental seorang pesilat sangatlah dominan baik saat berlatih ataupun saat ia menjadi seorang pesilat yang tangguh. Iringan jurus dengan menggunakan aba-aba kendang ataupun suara pelatih, harus dihayati dan dijiwai sehingga setiap jurus yang diajarkan sangat terasa mengalir dalam jiwa dan raga peserta. Tidak jarang atau bahkan sudah diwajibkan bahwa pada saat sebelum memulai atau mengakhiri latihan, setiap peserta diwajibkan untuk memanjatkan doa kepada Tuhan Yang Mahaesa agar ilmu silat yang saat itu tengah diajarkan kepada peserta dapat membawa manfaat, setidaknya bagi dirinya ataupun bahkan kepada masyarakat luas. Tidak ada dalam sebuah perguruan silat yang mengajarkan seorang peserta kelak dapat membawakan jurus silatnya pada jalan yang tidak benar bahkan mencelakakan orang lain.

Perihal pelatihan aspek mental spiritual sebenarnya adalah relatif karena bergantung dari bawaan aliran silat itu sendiri. Ada memang aliran silat yang mengharuskan pesilat untuk melakukan meditasi dalam bentuk tapa dan puasa sebagai salah satu syarat kelulusan dalam mempelajari aliran silat tertentu. Hal ini memang pernah - atau masih - ada di Kabupaten Purwakarta, yaitu tingkatan pelatihan untuk melatih Jurus Pamacan. Pernah ada kejadian tatkala proses pelatihan tidak berjalan sempurna yaitu dalam bentuk tapa. Selama dalam masa tapa pesilat tersebut menghadapi gangguan dari makhluk halus sehingga gagal dalam mengikuti ujian tersebut. Dampak yang ditimbulkan adalah ia berperilaku seperti tidak waras dan menunjukkan beberapa jurus yang mirip seekor macan.

Sikap untuk memperkuat batin menjadi sangat penting artinya. Setelah contoh tersebut di atas, ada juga informan yang menceritakan kejadian seorang pesilat di daerah Koncara yang berperilaku sangat aneh dan tidak masuk akal, yaitu dapat merayap di dinding sambil merusak barang-barang di sekitarnya. Latar belakang dari kejadian tersebut adalah tatkala seorang pesilat tersebut - sebenarnya sangat sepele menendang kaleng bekas dengan tidak sengaja. Entah kenapa pesilat tersebut 
langsung berperilaku seperti kejadian di atas. Butuh waktu yang agak lama untuk menyembuhkan perilaku pesilat tersebut. Pengobatan spiritual adalah yang paling sering dilakukan untuk menyembuhkan pesilat yang terkena pengaruh gaib tersebut.

Masih adanya beberapa aliran jurus "gaib" di Kabupaten Purwakarta tidak lepas dari pengaruh unsur kebudayaan lama yang masih melekat pada warga setempat. Mereka beranggapan bahwa seorang jago silat selain mahir dalam ketangkasan juga harus di-eusi dengan ilmu kanuragan. Jurus kelihaian seekor macan, elang, monyet, dan lain-lain tentunya tidak begitu saja dianggap mahir tanpa dibekali dengan insting dan kekuatan layaknya binatang yang dipelajarinya tersebut.

Penggunaan pola gerak yang bersumber dari fauna ini juga yang melatarbelakangi beberapa jurus dalam aliran silat Cimande. Sang pendiri aliran Cimande pernah bercerita tentang asal mula jurus yang diciptakannya, dan sangat berkait erat dengan fauna yang pernah dilihat atau diamatinya. Ia bercerita bahwa pada suatu waktu ia pergi ke sungai pada pagi hari untuk mencuci dan mengambil air. Saat hendak melakukan aktivitas tersebut, ia tertegun karena melihat harimau berkelahi dengan 2 ekor monyet dan salah satu monyet memegang ranting pohon. Saking seru melihat kelincahan perkelahian tersebut, ia sampai terkesima oleh gerakan yang diperlihatkan dalam perkelahian hewan yang memakan waktu hingga menjelang malam hari. Ia mencoba mengingat semua gerakan dalam perkelahian tadi. Untungnya baik harimau maupun monyet banyak mengulang-ngulang gerakan yang sama sehingga sangat membantu untuk mengingat semua gerakan tersebut. Akhirnya ia pun berlatih sendirian di pinggir sungai sampai menjelang tengah malam sampai betul-betul menguasai semua semua gerakan tersebut.

Melihat pola pengamatan dari binatang tersebut, Koentjaraningrat (1981: 138 - 139) adalah sama halnya dengan karakter kedua makhluk hidup tersebut (manusia dan binatang), yaitu selalu mempelajari keadaan di sekitarnya. Walaupun demikian ada perbedaan dalam pembentukan karakter kedua makhluk. Binatang memanfaatkan pelajaran tersebut untuk dipergunakan sebagai hal yang bersifat naluriah dan tetap berkelakuan secara membabi buta (behaviour). Sementara manusia mempergunakan keahlian dari hasil pelajaran dan pengamatan tersebut untuk dipergunakan dalam pembentukan tindakan atau tingkah laku yang terstruktur (action). Khusus dalam pengamatan perilaku yang dipergunakan untuk pertahanan diri, adalah bersifat fleksibel karena setiap ada perilaku baru yang dianggap lebih maju atau tinggi daripada ilmunya maka ia dengan segera akan mempelajarinya. Selanjutnya, menerjemahkan perilaku manusia adalah sangat dinamis dan bergerak sangat cepat dengan mengikuti perubahan yang sedang terjadi dalam lingkungan di sekitarnya. Walaupun demikian setiap tindakan akan selalu ada nilai dan norma yang membatasi ruang gerak manusia agar arah pergerakan dapat sesuai dengan aturan yang telah ditetapkan bersama dalam sebuah kelompok masyarakat. Hal inilah yang diistilahkan dalam Pencak Silat sebagai pembinaan mental spiritual. 


\section{Strategi Adaptasi Ditinjau dari Seni Budaya}

Budaya dan permainan "seni" Pencak Silat ialah salah satu aspek yang sangat penting. Istilah pencak pada umumnya menggambarkan bentuk seni tarian Pencak Silat, dengan musik dan busana tradisional. Seni dalam Pencak Silat memiliki kaitan yang sangat erat. Olah tubuh pada mulanya bertujuan untuk pertahanan diri dari serangan musuh. Khususnya di Purwakarta dan umumnya Jawa Barat, istilah Pencak Silat lebih dikenal dengan sebutan buah atau eusi. Lama kelamaan Pencak Silat kemudian juga diperkaya dengan dimasukannya unsur seni dalam bentuk pola gerak yang biasa disebut kembang atau ibing. Dengan demikian kata "pencak" oleh banyak masyarakat di Purwakarta lebih ditujukan bukan pada unsur pembelaan diri namun lebih mengarah pada suatu seni ibing Pencak Silat yang diambil dari gerak serangan dan belaan.

Seni Ibing ini merupakan jenis kesenian Pencak Silat yang berada di seluruh pelosok Kabupaten Purwakarta. Salah satu daerah yang dikatakan berhasil mengembangkan seni budaya tradisional termasuk ibing Pencak Silat adalah Desa Sawah Kulon Kecamatan Pasawahan Kabupaten Purwakarta. ${ }^{15}$

Ibing Pencak Silat terlahir tidak dengan begitu saja mengubah pola gerak

15 Ibing Pencak Silat yang berada di Desa Sawah Kulon Kecamatan Pasawahan Kabupaten Purwakarta termasuk dalam lingkup seni yang saat ini digabungkan dengan seni ulin kobongan. seni Ulin Kobongan merupakan sebuah kesenian tradisional yang bernafaskan islam yang ada di daerah Purwakarta tepatnya di Desa Sawah Kulon. Seni Ulin Kobongan yang lahir sekitar tahun 2002-2003 ini tercipta menjadi seni pertunjukan tanpa alasan yang berarti. Utamanya adalah tujuan Pencak Silat itu sendiri sebagai salah satu bagian dalam pertahanan sekaligus serangan terhadap musuh yang datang. Tentu saja untuk tujuan tersebut pada zaman penjajahan adalah sangat tabu bagi penjajah untuk membiarkan begitu saja Pencak Silat berkembang pesat. Oleh karena itu, strategi penjajah (Belanda) adalah menghancurkan banyak perguruan silat yang dengan jelas mengarahkan keahliannya untuk menyerang penjajah. Hal inilah yang membuat para pendekar atau guru silat menyamarkan tujuan Pencak Silat itu sendiri, yaitu dengan mengarahkan pada unsur seni dan dibuat sedemikian rupa sehingga sangat mirip dengan tarian atau yang saat ini dinamakan ibing Pencak Silat.

dari tiga jenis kesenian yang tumbuh dan berkembang terlebih dahulu, yaitu seni Kuntulan, Pencak Silat, Terbangan dan sholawat barjanji, dengan mengambil esensinya secara garis besar selanjutnya di kembangkan oleh para seniman, tokoh masyarakat, dan aparat pemerintah dalam hal ini dinas pariwisata. Seni Ulin Kobongan menggunakan alat musik atau waditranya terdiri dari 4 rebana/ genjring, kendang, bedug, dan tarompet. Gerakan mengambil dari gerak-gerak Penca yang khas daerah Purwakarta yaitu gaya Pleredan. Disinyalir bahwa Purwakarta sebagai kota Kabupaten tidak memiliki sebuah kesenian khas yang dapat mewakili seluruh kesenian yang ada. Untuk itu para seniman, masyarakat serta aparat pemerintah menciptakan sebuah kreasi kesenian baru yang dapat dijadikan kebanggan masyarakat Purwakarta, maka terciptalah seni Ulin Kobongan. 
Secara sekilas ibing Pencak Silat memang mirip dengan tarian daerah pada umumnya yaitu banyak mengggunakan pola gerak seperti penari. Walaupun demikian, tidak dapat disejajarkan antara ibing Pencak Silat dengan nama sebuah tarian karena dalam unsur gerak ibing selain terlihat jelas adanya unsur keindahan, tetapi di dalam keindahan tersebut pola gerak yang diperagakan juga dapat digunakan sebagai salah satu gerak pertahanan diri dalam menghadapi serangan musuh. Seperti halnya dalam silat Paleredan yang tersebar pada setiap kecamatan di Purwakarta, adalah dapat dikatakan sama dengan ibing Pencak Silat. Selanjutnya adalah gerak silat Cimande terutama pada jurus terakhir, yaitu jurus Tepak Selancar juga dapat menjadi bagian dalam memperkaya ibing Pencak Silat khas Cimande.

Memang dalam berbagai aliran Pencak Silat dapat dikatakan memiliki pola gerak ibing dan amat beragam pola gerak yang digunakan. Walaupun demikian, secara keseluruhan pola gerak dalam ibing memiliki unsur yang terbagi dalam tiga bagian yaitu wiraga, wirahma, dan wirasa. $^{16}$

\section{a. Wiraga 'kekayaan gerak'}

Wiraga yaitu variasi gerak atau jurus-jurus silat agar penampilannya dinamis saat tampil di atas pentas. Namun demikian variasi gerak menjadi tidak begitu diperlukan pada saat kaulan seperti halnya dalam acara hajatan. Perihal gerakan silat pada acara kaulan

16 Forum pecinta dan pelestari silat Tradisional Indonesia, "Aspek Seni Pencak Silat Tradisional", dalam http:// margaluyu-pusat.forumotion.net/t3aspek-seni-pencak-silat-tradisional, tanggal 27 Juli 2008. atau spontanitas yang diperlukan pesilat mampu memperagakan gerakannya dengan baik dan benar sesuai dengan kaidah Pencak Silat.

\section{b. Wirahma 'irama atau musik'}

Wirahma membedakan aspek seni dengan aspek yang lain dalam Pencak Silat. Kendang Pencak adalah merupakan sejenis alat musik tradisional - yang sekilas seperti degung Sunda ${ }^{17}$ - yang biasa digunakan untuk mengiringi pesilat yang tampil di atas panggung atau pentas dan alat tradisional ini sering digunakan dalam pertandingan Pencak Silat seni dan

17 Seni Degung adalah suatu seni karawitan Sunda yang menggunakan perangkat gamelan berlaras degung (lebih umum berlaras pelog). Pada umumnya gamelan ini terdiri atas saron, panerus, bonang, jengglong, gong, kendang, goong, serta suling. Seni kacapian adalah seni kawih Sunda yang menggunakan alat musik kacapi siter, suling, kendang, dan goong. Kadang-kadang menggunakan waditra rebab jika diperlukan. Bahkan, seni ini sangat potensial ketika harus diiringi hanya dengan sebuah alat kecapi siter saja.

Degung merupakan salah satu gamelan khas dan asli hasil kreativitas masyarakat Sunda. Gamelan yang kini jumlahnya telah berkembang dengan pesat, diperkirakan awal perkembangannya sekitar akhir abad ke-18/awal abad ke19. Jaap Kunst yang mendata gamelan di seluruh Pulau Jawa dalam bukunya Toonkunst van Java (1934) mencatat bahwa degung terdapat di Bandung (5 perangkat), Sumedang (3 perangkat), Cianjur (1 perangkat), Ciamis (1 perangkat), Kasepuhan (1 perangkat), Kanoman (1 perangkat), Darmaraja (1 perangkat), Banjar (1 perangkat), dan Singaparna (1 perangkat). 
acara khitanan atau acara kesenian daerah lainnya. Beberapa daerah yang masih mempergunakan peralatan tradisional ini selain Kabupaten Purwakarta, di antaranya daerah Bogor, Sukabumi, Bandung, Cianjur, dan Garut.

Perihal wirahma atau musik, ibing memerlukan beberapa waditra yang tergolong khas dalam setiap penampilan ibing Pencak Silat, yaitu:

a. Gendang induk.

b. Kendang kecil/kendang anak.

c. Terompet.

d. Gong.

\section{c. Wirasa 'penjiwaan gerak'}

Faktor penjiwaan gerak silat menjadi penentu dari seorang pesilat dalam setiap aktivitas gerak silatnya. Penjiwaandalamhaliniadalahpenguasaan Pencak Silat dari segi arti, makna, dan nilai falsafah yang terkandung dalam setiap jurus silat. Dengan memahami unsur-unsur tersebut, maka seorang pesilat tidak akan keluar dari alurnya dan berperilaku sesuai dengan falsafah dari Pencak Silat itu sendiri.

\section{Strategi Adaptasi Ditinjau dari Bela diri}

Kepercayaan dan ketekunan diri ialah sangat penting dalam menguasai ilmu bela diri dalam Pencak Silat. Istilah silat, cenderung menekankan pada aspek kemampuan teknis bela diri Pencak Silat. Pada dasarnya semua makluk hidup di bumi menginginkan hidup, mereka mempertahankan diri sesuai dengan alam dan budaya setempat. Kebutuhan utama untuk makan, minum, tempat tinggal, dan rasa aman mendorong mereka untuk terampil secara terus menerus menyempurnakan cara-cara membela diri sehingga dapat mengatasi dari serangan lawan maupun binatang.
Ciri dan corak bela diri dari masing-masing negara sesuai dengan adat istiadat masyarakat setempat. Namun pada prinsipnya ilmu bela diri mempunyai kesamaan yaitu membela diri bukan untuk menyerang terlebih dulu. Senjata, alat dan perlengkapan, serta asesoris disesuaikan dengan kebudayaan setempat. Teknik dan taktik yang membedakan bela diri adalah pada peraturan pertandingan, sehingga teknikteknik yang digunakan disesuaikan dengan peraturan.

Sejak zaman manusia purba, Tuhan telah menganugerahkan manusia dan seluruh mahkluk hidup di bumi untuk membela diri mempertahankan hidup dari serangan lawan atau ganasnya alam. Naluri membela diri tumbuh karena manusia terpaksa demi mempertahankan kelangsungan hidupnya. Cara mempertahankan diri manusia dari yang sederhana sesuai dengan perkembangan adat dan budaya sampai ke perkembangan dunia modern.

Pada zaman prasejarah bela diri dilakukan dengan amat sederhana yaitu dengan tangan kosong, batu, kayu, dan tulang untuk melawan binatang buas. Gerakan yang dilakukan juga masih sederhana sesuai dengan keadaan alam, dengan meniru gerakan binatang sebagai inspirasinya. Naluri untuk membela diri selain manusia, binatang pun dalam melangsungkan hidup tidak luput dari serangan baik alam maupun lawan. Sebagai contoh binatang yang melakukan bela diri adalah: (1) Trenggiling dengan menggulungkan badan, (2) Landak dengan menegangkan durinya, (3) CumiCumi dengan mengeluarkan tintanya, serta (4) pada tumbuhan Putri Malu membela diri dengan melayukan dirinya sehingga keluar duri-durinya. 
Setelah manusia bertempat tinggal tetap, maka sebagai makhluk hidup bermasyarakat mempunyai kebutuhan naluri untuk menjamin keamanan dan kesejahteraan diri. Sesuai dengan perkembangan budaya manusia maka mereka berpikir mengembangkan keterampilan untuk membela diri dari serangan lawan atau binatang. Keterampilan manusia untuk mempertahankan diri terus menerus dikembangkan dan disempurnakan sehingga menjadi ilmu bela diri yang berasal dari budaya setempat.

Pertemuan antara penduduk daerah yang satu dengan daerah yang lain, menyebabkan terjadinya tukarmenukar ilmu bela diri, sehingga dapat meningkatkan mutu bela diri di setiap daerah. Berbekal dari sejarah perjalanan pencipta silat Sahbandar yang hijrah dan meninggal di Wanayasa Purwakarta, serta beberapa aliran silat yang disebarkan di seantero Purwakarta, tampak bahwa seluruh aliran yang diajarkannya berirama khas Sunda meski ada beberapa campuran gerakan karena masing-masing perguruan ingin memiliki ciri khas mereka.

Gambaran bahwa silat Purwakarta dapat diseimbangkan dengan gerakan atau jurus silat yang ada di Jawa Barat, ada prinsip dasar yang melatarbelakangi ciri khas dari Silat khas Jawa Barat, yang juga dimainkan oleh para pesilat Purwakarta. Adapun ciri khas yang dimaksud adalah dalam bentuk gerakangerakan khas yaitu,

- pantang atau tidak suka mengangkat kaki;

- kuda-kuda lebar;

- selalu menghadapi lawan;

- tidak suka langkah surut;
- banyak lipatan-1ipatan (tangkapan);

- pencaknya mantap berirama.

Dari patokan gerakan silat di atas, sedikitnya agak berbeda dengan gerakan silat dari daerah lain. Misalnya, gerakan silat dari daerah Jawa Tengah (Solo) memiliki ciri khas yang banyak melakukan permainan bawah, tenang mengikuti dan meneruskan gerakan lawan, gerakan pencak seperti menari. Daerah lainnya, yaitu silat dari Jawa Timur memiliki ciri khas sigap, tegas, sedikit keras, dan beberapa kurang berirama. Sementara silat dari daerah Minangkabau memiliki ciri khas banyak menggunakan kaki, tangan membuka lebar, gerakan lentur dan indah.

Beberapa gerakan khas yang dibawakan masing-masing daerah termasuk Jawa Barat apabila dilihat dari beberapa segi ruang gerak, gerakan tangan kaki, suara, dan pernapasan memiliki kesamaan, yaitu,

- Bersifat halus, lemas, dan lentur, ada kekerasan sesaat.

- Tidak membutuhkan ruangan luas, sedikit lompatan atau gulingan (kecuali pamonyet dan pamacan).

- Tidak suka mengangkat lengan di atas bahu, kecuali sebagai pancingan.

- Tidak banyak suara (teriakan).

- Pernapasan wajar (kecuali perguruan tertentu).

- Banyak permainan rendah dan bawah.

- Tendangan sedang-sedang.

Tipikal silat tersebut di atas adalah sangat khas dan mencirikan karakter silat yang ada di Kabupaten Purwakarta pada khususnya, dan Jawa Barat pada umumnya. Dapat dikatakan bahwa tipikal ini sesuai dengan budaya Sunda yang 
memiliki prinsip lemah cai, membumi dan sangat berpenampilan sederhana serta tidak mencirikan kesombongan kepada orang lain baik yang dikenal maupun tidak dikenalnya.

Berbeda halnya dengan prinsip gerakan bela diri nonsilat. Sebut saja karate ataupun kuntau yang memiliki ciri khas gerakan menggertak dan berusaha melemahkan nyali lawan melalui efek pamer gerakan dan teriakan yang terlihat dari beberapa ciri gerakannya, yaitu:

- Tegap, keras, dan kaku, ada setiap saat.

- Membutuhkan ruangan luas, banyak lompatan, serangan, dan salto.

- Banyak sikap mengangkat lengan di atas bahu.

- Banyak suara (teriakan).

- Pakai pernapasan tertentu.

- Hampir tidak ada permainan rendah dan bawah.

- Banyak variasi tendangan.

Sangat banyak perbedaan antara gerakan silat dengan gerakan kuntau ataupun karate. Dari sisi keluwesan, silat jelas berbeda jika dibandingkan dengan sikap tegas, keras, dan kaku pada gerakan karate. Belum lagi sisi ruang gerak yang lapang pada gerakan karate sedangkan silat dapat melakukannya pada sedikit ruangan saja. Sementara pada gerakan lengan, silat tidak membutuhkan gerakan mengangkat lengan di atas bahu yang mana hal tersebut sangat dibutuhkan pada gerakan karate ataupun kuntau. Efek teriakan yang sebenarnya berfungsi sebagai upaya melemahkan semangat lawan pada karate tidak begitu dibutuhkan pada gerakan silat. Alhasil, pola pernapasan akibat efek teriakan pada karate sangat diperlukan untuk mengantisipasi agar tidak tersengal- sengal saat bertanding. Sementara silat hanya membutuhkan pola pernapasan sewajarnya saja karena tidak ada efek teriakan yang sangat keras. Pola membumi dalam gerakan silat yang diperlihatkan pada banyaknya permainan bawah bertolak belakang dengan gerakan karate yang lebih mengandalkan gerakan atas. Efek dari permainan bawah pada gerakan silat adalah tidak begitu diperlukan banyak variasi tendangan, yang mana hal tersebut sangat diperlukan pada gerakan karate atau kuntau karena banyak mengandalkan permainan atas.

\section{Strategi Adaptasi Ditinjau dari Olahraga}

Strategiiniberartibahwaaspekfisik dalam Pencak Silat ialah penting. Pesilat mencoba menyesuaikan pikiran dengan olah tubuh. Kompetisi ialah bagian aspek ini. Aspek olahraga meliputi pertandingan dan demonstrasi bentuk-bentuk jurus, baik untuk tunggal, ganda atau regu. Pencak Silat sebagai sebuah olahraga bela diri yang saat ini sudah mendunia tampaknya masih menjadi harapan bagi berbagai perguruan silat Purwakarta untuk terus mengembangkan karir pesilat mereka agar mampu berprestasi dalam berbagai ajang kejuaraan dunia. Rintisan karir yang ada saat ini masih belum begitu menggembirakanmengingatmasih sangat sedikit atlit silat yang membawa nama Purwakarta ke kancah kejuaraan minimal di tingkat nasional. Padahal apabila mereka sudah mencapai tingkat nasional bukannya tidak mungkin akan mengikuti berbagai kejuaraan hingga ke tingkat antarnegara. Walaupun demikian, untuk maju hingga ke tingkat negara, misalnya, sangat diperlukan pengetahuan mengenai peraturan Pencak Silat yang dibakukan pada negara penyelenggara tersebut. 
Hal ini tentunya berbeda apabila Pesilat Purwakarta maju ke tingkat kejuaraan Internasional yang menggunakan standar baku peraturan yang harus diikuti semua negara peserta.

Perihal standar baku peraturan Pencak Silat dari negara lain adalah karena Pencak Silat sudah mendunia dan banyak warga negara lain yang berminat untuk berlatih sekaligus mendirikan organisasi Pencak Silat di negara mereka. Hingga saat ini setidaknya sudah ada sekitar 34 negara yang memiliki wadah organisasi Pencak Silat di negara mereka.

Hal itu setidaknya dapat menjadi pelajaran yang berharga bagi Deni Heriyanto dan Ade Tirta Kamandanu, dua orang yang telah dan masih berkiprah sebagai atlit Pencak Silat Kabupaten Purwakarta, terutama, melatih siswa Pencak Silat yang tidak hanya dibekali dengan berbagaijurus silat melainkanjuga tata cara dalam mengikuti pertandingan minimal antarkabupaten dan maksimal adalah tingkat negara.

\section{PENUTUP}

Beberapa hal yang dapat disimpulkan dari penelitian ini dapat diklasifikasikan berdasarkan kondisi sumber daya manusia, dan peranan pemerintah dalam melestarikan kebudayaan daerah khususnya Pencak Silat. Kondisi sumber daya manusia di Kabupaten Purwakarta dalam kaitannya dengan pelestarian seni Pencak Silat sebenarnya sangat mendukung karena didukung oleh masih adanya rasa untuk melestarikan seni budaya dalam diri masyarakat itu sendiri, walaupun dalam kenyataan hanya pada beberapa daerah saja yang masih memegang teguh prinsip seperti itu, di antaranya di Kecamatan
Pasawahan, Wanayasa, Purwakarta, dan Plered. Pada kecamatan lainnya memang masih ada warga yang masih berniat melestarikan tradisi khususnya Pencak Silat namun dalam skala yang sedikit. Hal itu dimungkinkan oleh semakin masuknya budaya global, sehingga untuk tindak lanjut pelestarian Pencak Silat sedikitnya telah mulai ada hambatan.

Peranan pemerintah daerah KabupatenPurwakartauntukmelestarikan seni budaya Pencak Silat saat ini dapat dikatakan cukup menggembirakan. Arahan agar tiap sekolah dari berbagai tingkatan, melalui Dinas Pendidikan, agar turut menyertakan Pencak Silat dalam mulok (muatan lokal) ditanggapi oleh sekolah dan sudah cukup berhasil. Terbukti dengan beberapa siswa yang meraih prestasi menggembirakan dalam berbagai kejuaraan baik antar sekolah, ataupun antarkabupaten. Terkait juga dalam hal pengembangan seni Pencak SilatadalahDinas Kebudayaan Kabupaten Purwakarta yang turut mengembangkan seni ulin kobongan, yang di dalamnya disertakan ibing Pencak Silat, merupakan sebuah terobosan agar seni Pencak Silat tidak hanya disalahartikan sebagai sebuah seni bela diri atau olahraga semata melainkan dapat dikolaborasikan dengan jenis kesenian yang lain. Perihal keolahragaan yang menjadi salah satu unsur dalam seni Pencak Silat, Dinas Pemuda dan Olahraga Kabupaten Purwakarta juga telah beberapa kali menyeleksi pesilat-pesilat Purwakarta agar dapat diikutsertakan dalam berbagai kejuaraan, utamanya antarkabupaten.

Prestasi yang cukup menggembirakan dalam dunia Pencak Silat di Kabupaten Purwakarta adalah sebuah pergerakan dinamis. Artinya bahwa apabila tidak ditindaklanjuti 
makna sebuah prestasi bukannya tidak mungkin prestasi tersebut akan mengalami degradasi pada tahun atau periode berikutnya. Kehidupan atlit Pencak Silat juga patut diperhatikan. Status sebagai atlit yang mengharumkan nama daerah agar dipertimbangkan atau dapat disamakan dengan sebuah pekerjaan yang memberi kenyamanan dalam kehidupan ekonomi atlit itu sendiri. Dengan demikian, atlit Pencak Silat tersebut tidak lagi dipusingkan dengan masalah ekonomi rumah tangganya, yang tentunya dapat mengganggu konsentrasi dirinya untuk meningkatkan prestasi Pencak Silat.

Sosialisasi Pencak Silat kepada masyarakat juga harus ditingkatkan terutama dalam aspek silat sebagai sebuah olahraga dan pembinaan mental spiritual. Aspek silat sebagai sebuah olahraga sekaligus pembinaan mental spiritual pada awal sosialisasi dapat dilakukan di lingkungan kantor. Dengan demikian, selain dapat meningkatkan kebugaran pegawai sekaligus dapat turut melestarikan seni Pencak Silat itu sendiri.

Sosialisasi Pencak Silat juga dapat dilakukan di lingkungan masyarakat umum. Wadah yang sekiranya mudah untuk melakukan sosialisasi Pencak Silat tersebut adalah pada Karang Taruna di setiap desa atau kelurahan. Aspek yang diutamakan adalah aspek olahraga dan pembinaan mental spiritual. Tipe pelatihan yang dianjurkan adalah ibing Pencak Silat karena sifat ibing itu sendiri selain merupakan olahraga juga lekat dengan unsur kesenian. Akan halnya jadwal pelatihan yang biasanya hanya bersifat kesukaan saja dapat diantisipasi dalam bentuk kejuaraan ibing Pencak
Silat antarKarang Taruna. Apabila pola tersebut dilakukan bukan tidak mungkin Pencak Silat di Kabupaten Purwakarta dapat maju dan berkembang.

\section{DAFTAR PUSTAKA}

\section{Buku, Suratkabar dan Majalah}

Koentjaraningrat. 1993.

Manusia dan Kebudayaan

Indonesia, Jakarta: Jambatan.

Majalah Gema Pencak Silat Tahun ke 4 No. 1 Januari 2000

Permas, A., C. Hasibuan-Sedyono. 2003. L.H. Pranoto, dan T. Saputro, Manajemen Organisasi Seni Pertunjukan, Jakarta: Pustaka Binaman Pressindo, 2003.

Surbakti, Ramlan A. 2005.

"Teori dalam Penelitian Ilmu Sosial", dalam Bagong Suyanto dan Sutinah (ed) Metode Penelitian Sosial: Berbagai Alternatif Pendekatan, Jakarta: Kencana, 2005.

Yani, 2007.

"Seni Ulin Kobongan di Desa Sawah Kulon Kecamatan Pasawahan Kabupaten Purwakarta",Skripsi,Bandung: Universitas Pendidikan Indonesia. 


\section{Media Elektronik}

Taufan Prasetya.

"Sekilas Pandang Perguruan

Seni Pencak Bandarkarima

Latar Belakang Sejarah", d a la m http: // w w w silatindonesia.com/mod. php $\bmod =$ publisher\&op $=$ viewcat\&cid=12 Minggu, 19 Maret 2006 pukul 11:20:57.

Forum pecinta dan pelestari silat Tradisional Indonesia. 2008.

"Aspek Seni Pencak Silat Tradisional", dalam http:// margaluyu-pusat. forumotion. net/t3 -aspek-seni-pencaksilat-tradisional, tanggal 27 Juli 2008. 